\title{
ベッドの高さの違いからみた移動援助時の患者の頚部筋負担及び 看護師の作業効率への影響*
}

\author{
田丸朋子 $* *$, 阿兽洋子 $* *$, 伊部亜希**, 本多容子 $* *$, \\ 木村 静***, 鈴木みゆき****, 徳重あつ子 $* * * * *$
}

\begin{abstract}
This study examined the difference of nurse's work efficiency by changing the height of beds, and how the difference of nurse's working efficiency influences the patient's neck muscle load. 15 healthy women over 70 years old participated in this experiment as the patient role. One researcher, assuming the nurse role, performed patient transfers in two different bed heights : easy and uneasy working height beds. When the bed was set to the uneasy working height, patient's backbone was more lifted, and took more time to complete the transfer. These results show that nurse's working efficiency is decreasing when patient transfer is performed at uneasy working height. Moreover, at the uneasy working height, patient's neck hyperextension angle and integrated electromyogram of sternocleidomastoid muscles showed larger values than those of easy working height. The reason of this phenomenon is, as it is not comfortable lying with lifted backbones and retroflexed necks, patients attempted to draw in their chin unconsciously. Therefore, it can be said that, when patient transfer is performed at an uneasy working height, nurse's working efficiency decreases and patient's neck muscle load increases.
\end{abstract}

本研究では, ベッドの高さの違いによる看護師の作業効率の違いが患者の頚部筋負担に及ぼす影響を検証

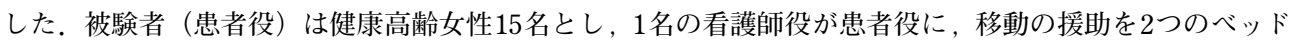
の高さ（易作業高：看護師役身長の $49 \%$ ，及び不易作業高：同 $32 \%$ ）で実施した．異なるべッドの高さ間 で, 胸鎖乳突筋の積分筋電図, 最大脊柱挙上角度, 頝部後屈角度, 援助の所要時間に有意差がみられた。こ れは不易作業高での援助時，看護師役が患者役の宜柱を挙上し，患者役の頝部がより後屈し，このような姿 勢が安楽でないために患者役が無意識に顎を引き，頝部筋負担が増大したと考えられる．安楽でない姿勢を 取る時間の延長も患者には負担であるといえる．看護師役の作業効率の低下は，患者役を動かすのに必要な 分力の減少による所要時間の延長からわかる。つまり，不易作業高での援助時，看護師の作業効率は低下 し，患者の頝部筋負担を増加させる.

(キーワード：ベッドの高さ，作業効率，頝部筋負担）

\section{1.はじめに}

一般的に病院で患者が使用するべッドは普段，昇降し やすいように，あるいは転落しないように， $50 \mathrm{~cm}$ あい

*受付：5月18日 受理：2010年1月8日

**大阪大学大学院医学系研究科保健学専攻

Course of Health Science, Graduated School of Medicine, Osaka University

***元大阪大学大学院

Osaka University

****兵庫医療大学看護学部看護学科

Department of Nursing, Hyogo University of Health Science

$* * * * *$ 明治国際医療大学看護学部

School of Nursing Science, Meiji University of Integrative Medicine
はそれ以下の高さに設定している1 3) 。しかしその高さ は，援助を行う看護師には低すぎる高さである．低すぎ るべッドでの援助，特に移動援助のような患者の体重が 大きく関与する援助は，看護師が過度な前傾姿勢をとら ざるを得ないことから, 腰部への負担が大きいとの研究 結果があり ${ }^{4,5)}$, ベッドの高さを調節する必要性が叫ばれ ている。しかしべッドの高さ調節は，面倒である，多忙 であるといった理由から省かれがちであり ${ }^{6)}$ ，看護師は低 いべッドのままで援助することが多い現状である.

人間工学の考えに則ると, 作業者である看護師は自身 の作業能力とその限界を知り，仕事を作業者の特性に適 合させなければならない7)とされる。そのため，看護の 教育現場では，作業に合わせた身体の使い方，いわゆる 「ボディメカニクスの活用」が指導されてきている，ボデ 


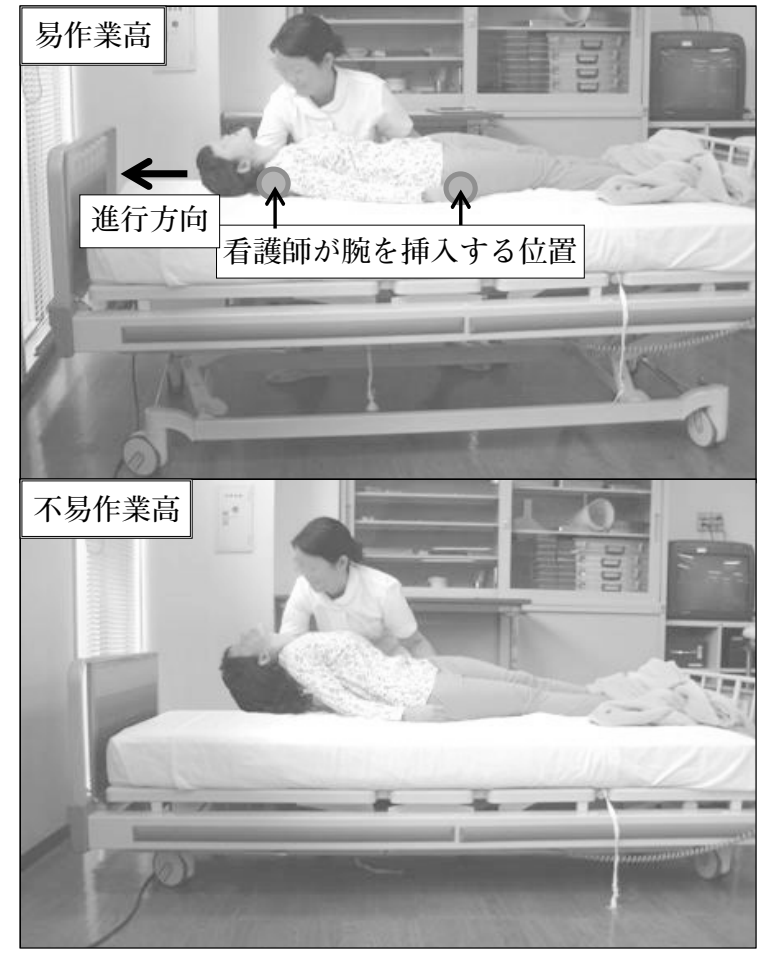

図 1 移動の援助

Fig. 1 Patient transfer.

イメカニクスの活用は, 活用しない場合に比べ, 看護援 助時の負担を軽減させることが明らかとなっている ${ }^{8)}$ が, ベッドの高さ調節を省くといった, 適切な作業環境を考 慮しないままでの作業は，十分な負担軽减がなされない．

低すぎる作業面高での大きく前傾した姿勢では，作業 効率の低下が起こることを示した先行研究がある9).ま た，作業効率が低下することで，作業対象に必要のない 方向や必要以上の力が加えられてしまうという, タッピ ンねじを用いた実験結果もある ${ }^{10)}$. 看護援助においては, 作業対象は患者であり人間である。つまり, 看護師の作 業効率の低下は看護師だけの問題ではなく, 必要以上の 力や必要のない方向への力が患者の身体に加えられるこ とにより, 看護師の作業効率の低下が患者に対し, 何ら かの負荷をかけるのではないかと考えられる。しかし， 看護援助時のベッドの高さの違いに言及した先行研究の 視点は, 打もに看護師の腰部負担にあり, ベッドの高さ による看護師の作業効率の違いが患者へ及ぼす影響につ いて述べられたものはない。

そこで本研究では, ベッドの高さの違いによって生じ る看護師の援助の違い（作業効率の違い）が患者の頝部 筋負担に及ぼす影響について検証することを目的とする. なお，本研究で取り上げた看護援助は，患者を頭部方向 に移動させる援助である。この移動の援助は, 看護師が 患者の身体の下に両腕を差し入れ，できるだけ患者を持
ち上げないように，患者を頭部方向へ水平に移動させる 援助である (図1)。この移動の援助では, 看護師の重心 が患者の重心と一定の距離を保ったまま行われることや， 単一動作であること，またてこの原理によらないことか ら，看護師の援助の違いが患者に伝わりやすいと考元， 今回の研究にて取り上げることとした。また，本研究に 打ける作業効率とは，「患者の移動した距離/看護師の加 えた力の水平方向への分力」と定義し, 作業効率の低下 を援助の所要時間の延長と，患者の身体を移動させるの に必要な力の量の減少でとらえるものとする.

\section{2. 研究方法}

\section{2-1. 被験者}

被験者（以下患者役）は，70歳以上の健康高齢女性 15 名とした，移動援助は，看護師と患者の体格差が大きい 場合は 2 人以上もしくはリフトなどを使用することが原則 である. 今回は 1 名の看護師役 (身長 $158 \mathrm{~cm})$ が一人で 移動援助を行うため, 男性に比べて小柄で体重の軽い, 女性に限定して募集した。

実験に際し，患者役には実験前日から過度の飲酒や激し い運動は控え，十分な睡眠をとるように依頼した。また， 当日の体調不良者は実験を行わす除外する旨も伝えた。

\section{2-2. 実験方法}

\section{2-2-1. 使用物品}

ベッドは 3 クンクタイプのベッドの上にパラケアマッ トレス（ともにパラマウント社製）を置き，すべての心゙ ッド柵を外して使用した。 パラケアマットレスの上にマ ットレスパットを敷き，その上に綿100\%の敷きシーツを 敷いた。また，患者役が着用する綿100\%のパジャマも用 意した.

\section{2-2-2. 測定項目}

(1)基礎データ

身長, 体重, 年齢, 体温, 血圧, 脈拍, 現病·既往歴, 服薬の有無.

(2)左右胸鎖乳突筋の筋電図

患者役の右の乳様突起と頸切痕をつなぐ直線上の, 乳 様突起から $1 / 3$ の距離のところにある, 胸鎖乳突筋の導出 中点 ${ }^{11)} よ り$ 連続的に表面筋電図を測定した。この筋は人 間があごを引く動作の際に活動する筋肉であり，仰臥位 での頝部後屈に抗して姿勢を保つ際の中核筋である。測 定には表面筋電計（BIOMETRICS社）を使用し，サンプ リングレートは $1000 \mathrm{~Hz}$ とした。 


\section{(3)移動援助の記録}

援助開始直前から終了直後までを, ベッドの長軸中点に 直交する線上の, ベッド縁より $1.5 \mathrm{~m}$ 離れた場所でマット レス表面と同じ高さに設置したデジタルカメラ（IXY Digital 90-Canon社）にて動画として記録した。動画の撮 影にはデジタルカメラのスムーズ動画機能を使用した。こ のスムーズ動画機能はサンプルレート $60 \mathrm{~Hz}$ での撮影が可 能であり，1コマ単位で静止画に変換できるものである.

(4)立位時の写真

援助開始前に, 患者役の立位で頚部の後屈がない状態 での写真を, 患者役の右側面からデジタルカメラ（IXY Digital 90-Canon社）を用いて撮影した。

\section{2-2-3. 実験方法}

1）測定手順

本研究では，患者役が受ける援助の質を一定にするた め, 看護師役を 1 名に固定して患者役に対する移動援助を 行うという実験デザインとした. 看護師役は, 看護師免 許を有し一般病棟での勤務経験を有する，27歳の女性と した。この看護師役は, 実験を行う時点で移動援助に関 して十分な知識・技術を有しており，この実験中に繰り 返して援助を行うことによる習熟の変化は考えられない．

実験の手順は次のとおりである.

(1)患者役がどちらのベッドの高さから測定を開始するの かを, 研究者がランダムに割り振った。

(2)研究者から患者役に対し実験の説明を口頭および書面 にて行い，実験参加への最終的な同意を得た。その後， パジャマへ更衣してもらい, 基礎データの測定打よび 立位時写真を撮影した。

(3)ベッドへ移動し，「移動の援助とはどういうものか」を 理解してもらうため, 手順を口頭で説明しながら移動援 助を行った。この際のベッドの高さは比較条件のどちら にも該当しない，看護師の身長比 $40 \% の$ 高さで行った. 患者役には移動援助中，極力脱力するように指示した.

(4)患者役に, ベッド上のマットレスの足側の縁に踵がのる ように仰臥位で臥床してもらい, 筋電龱電極を貼付した. (5)ベッドおよびビデオカメラの高さを調節した.

(6)ビデオカメラ, 筋電計での測定を開始し, 看護師役が 移動の援助を行い, 患者役の頭頂部がマットレスの頭 側の縁から $10 \mathrm{~cm}$ 位置にくるように移動させた。

援助の際, 看護師役は患者役の左側に立ち, 腰のひね りや足の踏み変えなどを行わず, 重心移動のみで患者 役を移動させた。

(7)20分の休想を取ってもらった，その間，患者役の体位 は長座位もしくは端座位とした。休鄎時間の間にベッ ドおよびビデオカメラの高さを変更した
8)2回目の移動援助を，1回目と同様に同一の看護師役が 実施した。

(9)筋電図電極を外し，終了した。

2）設定したベッドの高さ

(1)易作業高ベッド（看護師の身長比 $49 \%$ の高さのベッド). 看護技術の教科書では，移動援助にはどのようなべッ ドの高さが適しているかという，明確な表記はなかっ た。そのため，同じく立位で行う「ベッドメイキング」 に適した高さであるとされる，立位でマットレスの表 面に手掌が軽く触れる程度の高さ ${ }^{13)}$ を易作業高と定め た。この高さを先行実験にて求めたところ, 看護師役 の身長比 $49 \%$ の高さで相関がみられた。この高さは， 小原が示す立位での力作業の際の作業面の高さのめや すである $49 \%{ }^{14)}$ と一致したことから，本研究での易作 業高を「看護師の身長比 $49 \% の$ 高さ」と設定した。

(2)不易作業高ベッド（看護師の身長比 $32 \% の$ 高さのベッド). 臨床の患者用ベッドの高さが約 $50 \mathrm{~cm}$ に設定されてい る1 3) ことから，全国の成人女性平均身長 $158 \mathrm{~cm}^{15)}$ に対 する，臨床の患者用ベッド約 $50 \mathrm{~cm}$ の比である $32 \%$ を求 めた。この高さは，小原が示す，「(立位での) 手の届く 範囲」では，「前屈あるいはしゃがむ高さの領域」とし て明記されている ${ }^{16}$ 。これらのことから，本研究での不 易作業高を「看護師の身長比 $32 \% の$ 高さ」と設定した。

\section{2-2-4. 分析方法}

(1)胸鎖乳突筋の筋電図

得られた筋電図から積分筋電困を算出した．積分区間 は，患者役の身体が動いている区間を用いた（図2）。積 分筋電図の大きさは，Kolmogorov-smirnov検定にて正規 性が確認されたため，異なるべッドの高さ間で対応のあ る検定を用いて比較した

(2)援助の所要時間

デジタルカメラで録画された動画より，ストップウォ

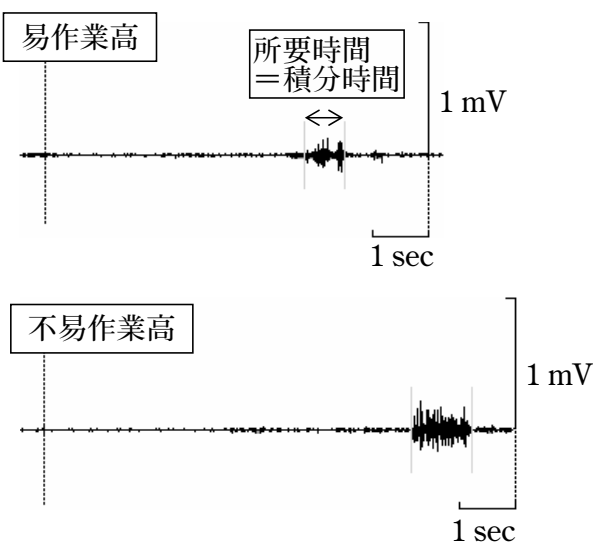

図2 移動援助中の筋電龱記録例

Fig. 2 Recordings of EMG during transfer. 
ッチを用いて援助の所要時間を計測した。計測区間は, 患者役の身体が動き出す瞬間を始点とし，移動後に患者 役の身体が静止するところを終点とした。これは, 筋電 図の積分区間とも一致する。得られた所要時間を, 異な るベッドの高さ間で対応のあるt検定を用いて比較した。

(3)金柱挙上角度 $(\angle \mathrm{B})$

デジタルカメラで録画された動画を，1/60秒毎に静止 画へ変換した。得られた静止画での, 腸骨稜と肩峰を結 ぶ線が，水平面とのなす角を分度器にて計測した。援助 開始から終了までの間における角度の最大值を, ベッド の高さごとに求めた. 各ベッドの高さでの最大脊柱挙上 角度を，対応のあるt検定を用いて比較した。

(4)頝部後屈角度 $(\angle \mathrm{A})$

脊柱挙上角度が最大值を取った時の頝部後屈角度を， 同じ静止画上で求めた。頚部後屈角度の算出には, まず 立位時の写真における腸骨稜と局峰を結ぶ線に対する， 耳珠点と顎先端を結ぶ線のなす角 $\alpha^{\prime}$ を求める. 同様に, 援助中の静止画におけるなす角 $\angle \alpha$ を求め， $\alpha-\alpha^{\prime}$ を䅡部 後屈角度 $(\angle \mathrm{A})$ として求めた. 頚部後屈角度は, 各べ ッドの高さ間で対応のあるt検定を用いて比較した。

いずれの検定も，統計ソフトSPSSver.12.0jを用いた。 な打，有意水準は $5 \%$ とした。

\section{2-2-5. 倫理的配慮}

本研究では, 研究目的及び研究方法を記載した文書を 用いて患者役となる被験者を募集した。被験者には, 研 究参加者募集への応募という形で参加同意を得, 研究参 加の意思表示があった時点で研究趣旨への同意が得られ たとした。また, 研究直前に再度, 口頭並びに書面にて 研究への協力と実験の途中辞退については自由意志であ ることを説明した。 また, 得られたデータはすべてID化 し数值のみの取り扱いとし, 研究目的以外では使用しな いことを説明した。

\section{3. 結 果}

\section{3-1. 患者役の基礎データ}

患者役の平均年齢は $72 \pm 2.6$ 歳, 身長の平均は $153.5 \pm$ $10.64 \mathrm{~cm}$, 体重の平均は $50.0 \pm 6.00 \mathrm{~kg}$ であった。

\section{3-2. 頚部筋負担指標（表 1）}

胸鎖乳突筋の積分筋電図では, 易作業高ベッドで $36.3 \pm$

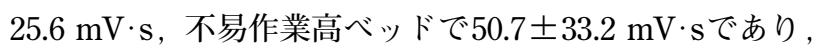

表 1 易作業高・不易作業高での比較 $(n=15)$

Tab. 1 Comparison between easy and uneasy working height.

\begin{tabular}{lccr}
\hline & $\begin{array}{c}\text { 易作業高 } \\
\text { 平均值 }(\mathrm{SD})\end{array}$ & $\begin{array}{c}\text { 不易作業高 } \\
\text { 平均值 }(\mathrm{SD})\end{array}$ & $\begin{array}{c}\mathrm{p} \text { 值 } \\
(\mathrm{p} \text { value })\end{array}$ \\
\hline 積分筋電図 $(\mathrm{mV} \cdot \mathrm{s})$ & $36.3(25.6)$ & $50.7(33.2)$ & $* * 0.004$ \\
援助の所要時間 $($ 秒 $)$ & $0.9(0.2)$ & $1.0(0.2)$ & $* 0.02$ \\
最大脊柱挙上角度 $\left(^{\circ}\right)$ & $4.3(2.3)$ & $7.5(3.7)$ & $* * 0.000$ \\
頝部後屈角度 $\left(^{\circ}\right)$ & $19.9(11.6)$ & $25.5(11.4)$ & $* * 0.000$ \\
\hline
\end{tabular}

両ベッドの高さ間で有意差が認められた $(\mathrm{p}<0.001)$.

\section{3-3. 援助の所要時間（表 1）}

援助の所要時間は, 易作業高ベッドで $0.9 \pm 0.2$ 秒, 不 易作業高ベッドでは $1.0 \pm 0.2$ 秒であり, 異なるベッドの 高さ間で有意差が認められた $(\mathrm{p}<0.05)$.

\section{3-4. 最大脊柱挙上角度, 頚部後屈角度（表 1）}

最大脊柱挙上角度は, 易作業高ベッドで $4.3 \pm 2.3^{\circ}$, 不 易作業高ベッドでは $7.5 \pm 3.7^{\circ}$ であり, 両ベッドの高さ間 で有意差がみられた $(\mathrm{p}<0.001)$. 頝部後屈角度では, 易 作業高べッドで $19.9 \pm 11.6^{\circ}$, 不易作業高べッドでは $25.5 \pm 11.4^{\circ}$ であり，両ベッドの高さ間で有意差が認めら れた $(\mathrm{p}<0.001)$.

\section{4. 考 察}

\section{4-1. 基礎データについて}

患者役の体格はいずれも標準的であり，特に体重は厚 生労働省から発表された平成17年度全国70歳以上の女性 平均体重である $49.7 \mathrm{~kg}^{15)}$ に近い值であった。厚生労働省 発表の全国の患者年齢分布では, 入院患者の $55 \%$ 以上が 70歳以上であるとされる ${ }^{17)}$. したがって今回の実験から 得られた結果は多くの病院や高齢者施設の患者像とほぼ 同様であると考えられる。

\section{4-2. 患者の姿勢と筋負担及び看護師の作業効率 について}

易作業高ベッドでの移動援助時に比べ, 不易作業高べ ッドでは胸鎖乳突筋積分筋電図の有意な増加, 患者の最 大脊柱挙上角度打よび颈部後屈角度の有意な拡大, 援助 の所要時間の有意な延長が見られた。

胸鎖乳突筋の筋負担と脊柱挙上角度の関係を考察する ため, 移動援助を受けている間に患者役が最も脊柱を挙上 していた時点の体勢をモデル化した（図3)。なお，モデル を簡略化するため, 頭部の重心と胸鎖乳突筋の停止部は同 


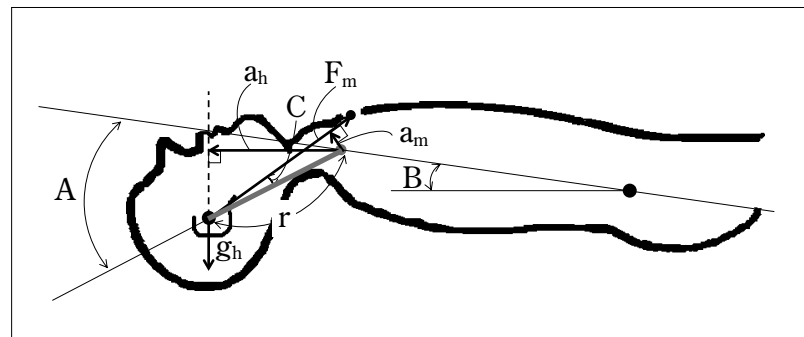

注)肩峰と鎖骨, 胸骨は同一直線状にあるとし , 頭部の重心 と胸鎖乳突筋停止部は同一であるとする。

図3移動援助中の被験者の体勢のモデル図

Fig. 3 Model of subject's position during transfer.

じ位置にあるとした。 また, 患者の頭部はマットレス表面 からは挙上しており, 垂直抗力を受けないものとする.

胸鎖乳突筋は鎖骨と胸骨から起こり，側頭骨の乳様突 起に停止する筋 ${ }^{18)}$ である，患者を真横から見た際，鎖骨 と胸骨は肩峰同一直線上とみなせる。このことから, 肩 峰を中心とした回転モーメントのつりあいを考えると， 以下のような等式が得られ, 胸鎖乳突筋の出力の大きさ が求められる.

$$
\begin{aligned}
g_{h} \times a_{h}=F_{m} \times a_{m} \\
F_{m}=\frac{g_{h} \times a_{h}}{a_{m}}=\frac{G \times r \times \cos (A-B)}{r \times \sin C} \\
=\frac{G \times \cos (A-B)}{\sin C}
\end{aligned}
$$

ここで, $\mathrm{g}_{\mathrm{h}}(=\mathrm{G}$, 定数 $)$ は頭部にかかる重力, $\mathrm{a}_{\mathrm{h}}$ はそ のモーメントアーム, $\mathrm{F}_{\mathrm{m}}$ は胸鎖乳突筋の出力, $\mathrm{a}_{\mathrm{m}}$ はそのモ ーメントアームである。また, rは耳孔と肩峰の直線距離, $\angle \mathrm{A}$ は頝部後屈角度, $\angle \mathrm{B}$ は脊柱挙上角度, $\angle \mathrm{C}$ は耳孔と 鎖骨を結ぶ線と, 耳孔と肩峰を結ぶ線とのなす角を表し, $\angle \mathrm{A}$ 大゙大くなるほど $\angle \mathrm{C}$ はさくなるという関係がある.

このつり合いの式から考えると, $\mathrm{F}_{\mathrm{m}}$ は $\angle \mathrm{A} と \angle \mathrm{B}$ の差 が大きく，かつ $\angle \mathrm{C}$ が小さ時に值が大きくなる。これ は, 脊柱が挙上され, 頚部が大きく後屈した体勢である. 患者役の移動援助中の体勢を易作業高と不易作業高で比 較した場合, 不易作業高での援助時の体勢の方がより脊 柱を挙上され，大きく頚部を後屈したものであった。つ まり，不易作業高での援助時の患者役の体勢の方が，乇 ーメントのつり合いの上では安定であり, 筋出力は易作 業高での援助時の体勢と比べると小さくなるはずである. しかし, 今回の結果では不易作業高での援助時の筋電図 積分地の大きさが有意に大きかった. これは患者役が体 勢を維持することに加えて, 後屈に抗う随意的な力を入 れていたと考えられる.

不易作業高での援助時のように脊柱が挙上されると, 頭部が重力に引かれて頝部が大きく後屈する．頝部には
脊髄や頚神経，椎骨動脈があり，頚椎骨はこれを取り囲 むように位置している，そのため，頚部を大きく後屈さ せる姿勢は, 高齢者に多い神経根症患者では痛みやしび れを誘発してしまうとされている ${ }^{19)}$ 。また，移動援助時 の姿勢と似た姿勢をとる，仰臥位での洗髪時においては， より後屈の大きかった場合にめまいや痛みが増加すると いう実験結果もあり，洗髪中の脳卒中による死亡例も報 告されている20,21)。このように，仰臥位で頚部を大きく後 屈することは, 力学的には安定かもしれないが，人間に とっては不快な姿勢であることから，無意識に，しかし 随意的に㴿を引くため，胸鎖乳突筋に力を入れていると 考えられる。逆に，筋力低下の著しい場合ではこのよう に随意的な筋出力が十分にできないことから，頚部の後 屈もより大きくなってしまうことも考えられる．また， 不易作業高べッドでの移動の際には，援助の所要時間も 有意に延長していた。看護援助において，作業時間が短 いことは患者の体動に急激な変化を与えることから，循 環器系への影響を考えると必ずしも良いこととはされな い.しかし今回のように, ベッドの高さの違い以外の援 助方法を同一とした場合に所要時間が延長してしまうこ とは，頝部の筋負担が大きくなる姿勢をとらなければな らない時間が延長している状態を示す。したがって，不 易作業高べッドで受ける移動援助では，安楽でない姿勢 を取らなければならない時間が延長することからも，易 作業高べッドでの援助時に比べ，患者の負担が増してい るといえる.

次に, 看護師の作業効率について考察する。不易作業 高ベッドでの援助時, 最大脊柱挙上角度が有意に大きか ったのは，このべッドの高さでの援助が看護師役にとっ て作業しにくいことから水平方向に力を加えられず，慰 部に比べ軽量な患者役の上半身を挙上してしまったと考 えられる．移動援助を行う際，患者役の頭部はどちらの ベッドの高さでも接触しておらず，また慰部の摩擦力は いずれの場面においても同じである。さらに，看護師役 も同一であることから，患者を移動させるのに加えた力 の大きさは易作業高・不易作業高双方において同一であ る。そのため，不易作業高でより大きく患者役の脊柱を 挙上させていることから，加えられた力の分散がより大 きく起こっており，患者役を移動させるのに必要な力の 水平方向成分の減少が推測できる（図4)。このように， 患者役を移動させる距離が同じであるにもかかわらず， 移動に直接関わる水平方向成分の力が減少したことから， 作業効率の低下が認められる。また，所要時間の有意な 延長もみられているが，これは力が減少した状態で同じ 距離を移動させるため，看護師役の作業効率の低下が所 


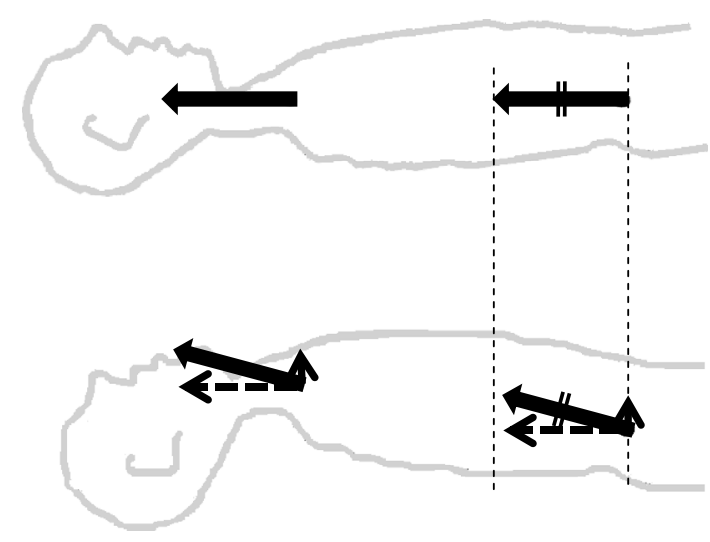

図4 力の水平方向成分の減少

Fig. 4 The reduction of the components of the force.

要時間の延長という形で現われていると考えられる.こ れらのことから, 不易作業高ベッドで行う患者の移動援 助では, 看護師の作業効率が低下し, 患者の頝部筋負担 をより増大させていると考えられる。 また, ベッドの高 さを看護師の易作業高に調節することは, 看護師の作業 効率の低下を防ぐだけでなく, 患者の頝部筋負担を減少 させられると考えられる。

\section{5. 結 論}

本研究にて, ベッドの高さの違いによって生じる看護 師の援助の違いが, 患者の頝部筋負担に与える影響の違 いを検証した結果，以下のことが明らかとなった。

(1) 看護師の不易作業高ベッドで行う移動援助では, 看護 師の作業効率の低下が認められた。そのため援助の所 要時間が延長し, 患者の脊柱が挙上されて頝部が後屈 しやすい状態となり, 患者の頚部筋負担が増大するこ とがわかった。

(2)ベッドの高さを看護師の易作業高に調節すると, 援助 の所要時間が短縮され, 脊柱挙上角度が小さくなっ た.さらに頝部筋負担も減少したことから, ベッドの 高さ調節は, 看護師だけでなく, 患者の頝部筋負担軽 減にも有効である。

\section{謝 辞}

本研究を実施するにあたり，ご理解・ご協力いただき ましたシルバー人材センターの皆様に御礼申し上げます.

\section{参考文献}

1）藤田きみ急, 横井和美ら : 看護作業姿勢と腰部への負担 に関する研究一滋賀県下湖東, 湖北地域における病院のべ ッドの高さ一, 滋賀県立大学看護短期大学部学術雑誌, 3 ,
1-7, 1998.

2）氏家幸子, 阿曾洋子：基礎看護技術 1 第 5 版, 190 , 医学 書院, 東京都, 2000.

3）横井和美, 伊丹君和ら：安全なべッドからの立ち上がり に関する研究（その2）－表面筋電図を用いた成人患者の 下肢筋力の検討一, 人間看護研究, 3, 29-37, 2004.

4）平田雅子：腰痛緩和の試みと看護のかかわり腰痛を引 き起こす姿勢, 動作一ボディメカニクスの観点からー, 看 護技術, 36, 1615-1619, 1990 。

5）加藤麻樹：介助作業の標準化に関する研究（その2）体位変換作業におけるべッドの高さと作業者に対する負 担との関連性一, 九州看護福祉大学紀要, 169-173, 2001.

6）土居恵里香, 小松万喜子：電動ベッド導入の有無別にみ た看護師の腰痛ならびにベッドの高さ調節の実施状況, 日 本看護学会論文集 : 看護総合, 38, 217-219, 2007.

7）小川鑛一：看護動作を助ける基礎人間工学：東京電機 大学出版局, 1999 .

8）伊丹君和, 藤田きみ总ら：看護作業時のひねりが看護者 の腰部に及ぼす影響についての検討（第2 報）一ベッド メーキング作業時の筋電図学的分析一, 滋賀県立大学看護 短期大学部学術雑誌, 6, 37-42, 2002.

9）井上薰, 河野光伸ら：作業姿勢とリフティング動作, 東 京保健科学学会誌, 2 (2), 85-88, 1999.

10）松本俊之, 志田敬介ら：タッピンねじ締め作業における 作業方向と作業位置が作業効率に及ぼす影響, 日本経営工 学会論文誌, 52, 332-343, 2002.

11) Zipp P : Recommendations for the standardization of lead positions in surface electromyography, Eur. J. Appl. Physiol., 50, 41-54, 1982.

12）本郷利憲, 廣重力ら：標準生理学 第3版, 99, 医学書院, 東京都, 1995 .

13）氏家幸子, 阿曾洋子：基礎看護技術 1 第 5 版, 209, 医学 書院, 東京都, 2000.

14）小原二郎「暮らしの中の人間工学」実教出版, 175 , 1971.

15）厚生労働省：身長 - 体重の平均值, 性 - 年次 X年齢別, 厚生統計要覧 平成19年度 第2編第1章 表2-6より算出, 2007, http://www.mhlw.go.jp/toukei/youran/indexyk_2_1. html

16）小原二郎「暮らしの中の人間工学」実教出版, $81,1971$.

17）厚生労働省：推計患者数 - 受療率（人口 10 万対） 入 院一外来 ·年次 $\times$ 性 · 年噛階級別, 厚生統計要覧 平成 19 年度第2編 第2章 60 表, 2007, http://www.mhlw.go. jp/toukei/youran/indexyk_2_2.html

18）Donnelly J. E. : 動きでわかる解剖と機能, 113, 医道の 日本, 東京都, 1999.

19）菊池臣一：整形外科外来シリーズ 5 頚椎の外来, 35 , メジカルビュー, 1998.

20) Foye P. M., Najar M. P. 5 : Pain, dizziness, and central nervous system blood flow in cervical extension : vascular correlations to beauty parlor stroke syndrome and salon sink radiculopathy, Am. J. Phys. Med. Rehabil., 81, 395-399, 2002.

21) Weintraub M. I. : Beauty parlor stroke syndrome : report of five cases, JAMA, 269, 2085-2086, 1993. 